\title{
Assessment on The Welfare Problem and Other Management Constraints of Equines in Debre Birhan Town, Central Ethiopia
}

\author{
Atirihun Mamo*, Assaye Wollelie, Getish Hilegiworgise and Yohannes Haileyesus \\ School of Veterinary Medicine, Hawassa University, Ethiopia
}

Submission: August 01, 2019; Published: November 15, 2019

*Corresponding author: Atirihun Mamo, School of Veterinary Medicine, Hawassa University, Hawassa, Ethiopia

\begin{abstract}
A cross-sectional study was done from November 2018 to April 2019 in Debre Birhan town, North Shoa zone, central Ethiopia. The objective of the study was to assess the welfare problem and other management constraints of working equine in the study area. A total of 120 working equine were observed for the presence of lesions, lameness, age and body condition score direct from the animal and 130 equine owners were interviewed to get information about feed type, workload and time and type of work. Most equine owners, 74.6\%, were fed mixtures of concentrate, cereal, straw and hay. Proportion of working time in a week $43.8 \%$ \& 35.4\% were grouped 3-4 days and 5-7 days respectively and $65.4 \%$ work 6-10 hours per day. The body condition score of working equines in the present study area were poor, moderate and good with a percentage of $34.2 \%, 48 \% \& 25.8 \%$, respectively. The owners practice vaccination (12.3\%), deworming (5.4\%) \& (43.1\%) both for prevention and control of equine diseases however $30 \%$ of respondents did not practice disease prevention measures. Among the observed equine $54.2 \%$, $25 \%$, and $20.8 \%$ were used for pack, draught and ridding respectively. Proportion of working type between donkey (69\%), horse (26.3\%), and mule (4.6\%) were used to pack and donkey and horse used for draught type of work with proportion of $13.3 \%$ and $86.7 \%$ respectively. On the other hand, according to obtained data horse (28\%) and mule (72\%) were used to riding type of work whereas donkey was not used to riding purpose in this study area. The common body lesion prevalent in the present study area $17.5 \%, 15 \%, 11.5 \%$, and $34.2 \%$ at tail base, lip, back sore and lacrimation respectively and $12.5 \%$ of equine were lameness $(66.7 \%), 86 \%$, and $83 \%$, Tail base lesions, of back sore, ribs/flank were more associated to work type of pack animal respectively. Draught type of work is likely to induce lip and mouth lesion (50\%), and lameness (73.3\%). In this study equine had an important value and act as multipurpose animal in the rural and urban society. However, management constraints like feed shortage, lameness, wound, over time working and overloading were found the main challenges hindering the health and welfare of equines. Therefore, further studies and necessary measures should be considered on the diseases and welfare constraints hindering efficient use of equine in the area of paramount importance.
\end{abstract}

Keywords: Welfare; Equine; Work type; Body condition scoring; Central statistics; Agricultural organization; Non-governmental organization

Abbreviations: BSC: Body Condition Scoring; CAN: Central Statistics Authority; FAO: Food and Agricultural Organization; NGO: NonGovernmental Organization; SPANA: Society for Protection of Animals Abroad

\section{Information}

Equines are widely distributed throughout the world. There are an estimated 90 million equines in the developing world, with highest population concentration in Central Asia and North and East Africa FAO, (2003) [1]. Ethiopia possesses approximately half of Africa's equine population with $37 \%, 58 \%$, and $46 \%$ of all African donkeys, horses, and mules, respectively CAN, (2014). Equines are the most important animals in the farming and transport systems of Ethiopia. Horses used for work are common in the developing world. They are used for draught, pack, agricultural work and riding [2] horses are used for draught, pack, agricultural work and riding and the owners are often from societies with poor economies, with incomes below the international poverty limit [3]. Because of the limited economic resources, as well as the lack of knowledge about animal management, the possibilities to give adequate cares to the horses are restricted [4]. Although in many countries including Ethiopia horses, donkeys and mules are kept mostly for transportation, there are few areas where equine meat and milk are consumed. In some areas of North West Kenya and Southern Ethiopia, donkey meat is a delicacy and the milk believed to treat whooping cough [5].

Despite their invaluable contributions, equines in Ethiopia are the most neglected animals, accorded low social status, particularly the male working equines. Horses involved in pulling carts often work continuously for 6 to 7 hours/day, carrying 3 to 4 persons $(195-260 \mathrm{~kg})$ in a single trip [6]. They are provided with grasses during the night and allowed to graze on pasture in the town fringe during the day. Donkeys often are involved in 
more multipurpose activities than horses. They transport goods to and from markets, farms, and shops, traveling long distances [7]. Some methods of hobbling to restrain cause discomfort and inflict wounds, poorly designed harnesses and raged have an effect on the equine health and safety [8]. Poor infrastructure and very rugged topography in many parts of rural Ethiopia have made transportation by vehicle inaccessible [9]. Hence farmers use alternative means like draught animals especially donkeys and horses to combat transportation problems [10]. In rural and peri-urban areas, people rely on equines to transport crops, fuel wood, water, building materials and people by carts or on their back from farms and/or markets to home. If equines are not available, women often have to do the same work [11].

Though disease and related problems are major constraints to their performance, information emanating from systematic investigation is almost non-existent. Long working hours and difficult conditions are experienced by donkeys and horses working in the area. Animals are often engaged in work for long hours and when get free, they are left to browse and feed on garbage. These have a potential to affect negatively their welfare and quality of life. This was justified by low number of donkeys presented annually to the clinic compared to other domestic animals, 270 donkeys vs. 20,000 head of other domestic animals, between [12]. This misuse, mistreatment and lack of veterinary care for equines have contributed enormously to early death, majority of which currently have working life expectancy of 4 to 6 years [13]. However, in countries where animal welfare practiced, the life expectancy of equine reaches up to 30 years [14].Research conducted in Ethiopia demonstrated that improvements in the welfare of equines had significantly improved their work output which in turn improved livelihood situations of the poorest communities in the rural and periurban areas [10]. The welfare of working equines in developing countries is therefore crucially important, not only for the health and survival of those animals, but also for the livelihoods of those people dependent on them [15].

The objectives this study were

a) To assess the community's awareness regarding equine welfare and

b) To investigate major welfare and health problems in equine associated with overworking and mistreatment in and around Debre Berhan town

\section{Materials and Methods}

\section{Study area}

The study was carried out from November 2018 to April 2019 in Debre Birhan town. Debre Birhan is the capital town of North Shoa zone of Amhara regional state and located at $120 \mathrm{~km}$ North East of Addis Ababa at $9^{\circ} 4^{\mathrm{N}}$ latitude and $39^{\circ} 32 \mathrm{E}$ longitude. The area has two bimodal rain falls consisting of long rainy season ("Kiremt") covering June to September and short rainy season ("Belg") extending from February to March. The average annual rain fall of the area is $956 \mathrm{~mm}$ the average temperature ranges from $6.3^{\circ} \mathrm{C}$ to $18.8^{\circ} \mathrm{C}$. The average relative humidity is $59.6 \%$.

\section{Study design and population}

The study design followed was a combination of crossectional questionnaire survey of equine owners and direct observation of selected equine for welfare and health problems. The study population consisted of randomly selected equine owners and equine (horse, donkeys and mules) irrespective of age, sex and colour.

\section{Sample size and sampling methods}

The total number of equines required for the study was calculated based on the formula given [16] for random sampling method. To compute the sample size, an expected prevalence of $25 \%$ based on similar previous studies [17] and 5\% desired absolute precision at confidence level of 95 present was used. The applied was.

\section{Where:}

$\mathrm{n}=$ required sample size

Pexp $=$ expected prevalence $=25$

$\mathrm{d}=$ desired absolute precision $=5 \%$

$1.96=$ value of $\mathrm{Z}$ at $95 \%$ confidence interval

$\mathrm{n}=288$

Accordingly, the sample size required for the study was 288 equine and equal numbers of equine owners. Simple random sampling technique was employed to select the study subjects.

\section{Study methodology}

\section{Questionnaire survey}

Primary data was collected through administering a structured questionnaire to randomly selected owners of equine at the study area. The questionnaire included various questions for the equine owners' concerning the awareness, veterinary services, economic and health aspects. Questionnaire administration was carried out by the researcher himself. A faceto- face interview method was followed to collect the required information from 130 equine owners. Based on the types of work animals were categorized as draught, pack and ridden. "Draught" animals are those used for transport of goods and people by carts. "Pack" animals are those used for transport of goods by pack. "Ridden" animals are those used by owners for transportation by back.

\section{Observational study}

Observations were carried out on study equine selected randomly from the study population regardless of age and species. The observation was carried out at the work site during daytime and at market. Initially, general information was recorded for each animal including their kebeles, work type and feeding practice. In the randomly selected areas almost all available 
donkeys were physically examined for lameness, body condition score, wound and Behaviours were recorded. The examination of each animal took between five and ten minutes without causing major interruption of routine work. Direct observations provide the measure of welfare status that is most relevant to the animal itself. Although animal-based observations are often assessed subjectively, they should provide a more direct, and therefore more valid, assessment of welfare than resource measurements. Repeatability (precision) of the observations is an important consideration and subjective health and behaviour assessments can be very repeatable [18].

The scoring of body condition of the selected animals was recorded based on the criteria described [19]. Body condition assessment was done by looking the animal from both sides and the hind quarter without touching the animals and scored as poor, moderate and good.

\section{Data Management and Analysis}

Data were collected according to species age, sex, work type and health aspect were recorded by hand and result (welfare and health parameter) was inserted into MS excel spread sheet Table 1: Demographic characteristics and type of animals owned by the and analysed by used descriptive statical method.

\section{Results}

\section{Questionnaire survey finding}

Out of the total equine owners included in the questionnaire survey $83.8 \%$ were male and $16.25 \%$ female. Most of the equine owners $(47.7 \%)$ were in the age group (15-30) while $27 \%$ and $25.3 \%$ were aged (31-45) and above 45 years, respectively. On the otherhand, $88.5 \%$ of the respondents had both ruminants and equine while $11.5 \%$ had only equine (Table 1 ). Regarding feed supply to equine, $35.4 \%$ of the respondents mentioned that they had shortage of feed for their animals and $23.1 \%$ of the owners used to purchase feed from market. Feed mainly consisted of concentrate, straw and barley. Most of the animal owners (74.6\%) provide mixtures of concentrate, cereal, and straw/hay to their animals while small (3.9\%) proportion give concentrates only. Some owners (16.2\%) provide straw only whereas $5.4 \%$ of the respondent feed a mixture of straw and hay as supplementary to grazing. Concentrate feed was a stuff which includes bear residues and frushica whereas cereals were barely and bean Table 2 .

\begin{tabular}{|c|c|c|}
\hline Variable & Frequency $(\mathrm{N})$ & Proportion (\%) \\
\hline \multicolumn{3}{|c|}{ Sex } \\
\hline Male & 109 & 83.8 \\
\hline Female & 21 & 16.2 \\
\hline \multicolumn{3}{|c|}{ Age } \\
\hline $15-30$ & 62 & 47.7 \\
\hline $30-45$ & 35 & 27 \\
\hline$>45$ & 33 & 25.3 \\
\hline \multicolumn{3}{|c|}{ Type of Equine Owned } \\
\hline Donkey & 72 & 55.4 \\
\hline Horse & 58 & 44.6 \\
\hline Animal ownership by species & 130 & 100 \\
\hline Equine (horse/donkey) and ruminants & 115 & 88.5 \\
\hline Equine only & 15 & 11.5 \\
\hline
\end{tabular}

Table 2: Type and source of feed for equine $(\mathrm{N}=130)$.

\begin{tabular}{|c|c|c|}
\hline Variable & Frequency $(\mathrm{N})$ & Proportion(N) \\
\hline \multicolumn{3}{|c|}{ Type of Feed provided to Equine } \\
\hline Concentrate, cereal and straw/hay & 97 & 74.6 \\
\hline Straw & 21 & 16.2 \\
\hline Straw, hay and grazing & 7 & 5.4 \\
\hline Concentrate & 5 & 3.9 \\
\hline \multicolumn{3}{|c|}{ Source of Feed for Equine } \\
\hline Purchase & 30 & 23.1 \\
\hline Self-farm & 100 & 76.9 \\
\hline \multicolumn{3}{|c|}{ Shortage of Feed for Equine } \\
\hline Yes & 46 & 35.4 \\
\hline No & 84 & 64.6 \\
\hline
\end{tabular}


Based on the types of work equine were categorized as draught, pack and ridden. "Draught" animals were those used for transport of goods and people by carts. "Pack" animals are those used for transport of goods by pack. "Ridden" animals are those used by owners for transportation. Accordingly, 54.3\% of equine were used to pack purpose, 33.8\% were for draught purpose and $16.9 \%$ were used for riding. The data obtained indicates that $55.4 \%$ of the respondents keep their animals outdoor in a fenced area without roof while $44.6 \%$ keep their animals indoor at night. Most of the animals (65.4\%) used to work for 6-10 hours per day while few (34.6\%) work for 1-5 hrs. Regarding the working days per week, a higher proportion $43.8 \%$ of equine work for $3-4$ days, while $35.4 \%$ and $20.8 \%$ work for 5-7 and 1-2 days respectively (Table 3). With regard to hoof

Table 3: Work type, work time, load, floor structure of equine staled.

\begin{tabular}{|c|c|c|}
\hline Variable & Frequency/N & Proportion (\%) \\
\hline \multicolumn{3}{|c|}{ Parent's Practice of keeping Equine } \\
\hline Yes & 94 & 72.3 \\
\hline No & 36 & 27.7 \\
\hline \multicolumn{3}{|c|}{ Parent's use of Equine } \\
\hline For pack & 60 & 46.3 \\
\hline For draught & 26 & 20 \\
\hline For riding & 14 & 10.8 \\
\hline Not had equine & 30 & 23 \\
\hline \multicolumn{3}{|c|}{ Respondent's use of Equine } \\
\hline For pack purpose & 65 & 50 \\
\hline For draught purpose & 44 & 33.8 \\
\hline For riding purpose & 21 & 16.2 \\
\hline \multicolumn{3}{|c|}{ Equine Working time per week in days } \\
\hline 2-Jan & 27 & 20.8 \\
\hline 4-Mar & 57 & 43.8 \\
\hline 7-May & 46 & 35.4 \\
\hline \multicolumn{3}{|c|}{ Workload of Equine in $\mathrm{kg}$} \\
\hline$<50$ & 12 & 9.23 \\
\hline $51-100$ & 51 & 39.2 \\
\hline $100-200$ & 23 & 17.7 \\
\hline $200-400$ & 35 & 27 \\
\hline$>400$ & 9 & 7 \\
\hline \multicolumn{3}{|c|}{ Equine Working hour per days } \\
\hline 5-Jan & 45 & 34.6 \\
\hline 10-Jun & 85 & 65.4 \\
\hline \multicolumn{3}{|c|}{ Care for Equine after Work } \\
\hline Provide feed and water \&grooming & 52 & 40 \\
\hline Grooming, provide feed \& water, provide sufficient rest & 38 & 29.2 \\
\hline Grazinggrooming, provide sufficient rest & 40 & 30.8 \\
\hline \multicolumn{3}{|c|}{ Floor Structure } \\
\hline Soil type of floor & 33 & 25.4 \\
\hline Concrete with drainage & 10 & 8 \\
\hline
\end{tabular}

care after work, most the equine owners (40\%) did not provide any care but $24.6 \%$ were trimming, $14.6 \%$ provide horseshoe, $18.5 \%$ practice both trimming and horseshoe and $2.4 \%$ practice only hoof cleaning when equine was suffered by hoof wound. Out of total equine owner, $77 \%$ had veterinary access while $23 \%$ had no access. Disease prevention practices by the equine owners included vaccination (12.3\%), deworming (5.4\%) and vaccination and deworming (43.1\%). A higher proportion (30\%) of the owners did not provide any treatment to their donkeys or horses, regardless of the presence and severity of diseases. This signifies the widely prevailing equine welfare problem in the area. When asked about the cost of treatment, $27 \%$ of the respondents said that the cost of treatment was expensive, $27 \%$ responded fair and16\% said cheap (Table 4). 


\section{International Journal of Environmental Sciences \& Natural Resources}

\begin{tabular}{|c|c|c|}
\hline Concrete without drainage & 15 & 11.5 \\
\hline Shelter without roof/outdoor & 72 & 55.4 \\
\hline
\end{tabular}

Table 4: Diseases prevention, care for hoof and cost of treatment $(\mathrm{N}=130)$.

\begin{tabular}{|c|c|c|}
\hline Variable & Frequency/N & Proportion (\%) \\
\hline \multicolumn{3}{|c|}{ Care for Hoof of Equine } \\
\hline Trimming & 32 & 24.6 \\
\hline Horseshoe & 19 & 14.6 \\
\hline Both trimming and horseshoe & 24 & 18.5 \\
\hline Cleaning & 3 & 2.3 \\
\hline No care & 52 & 40 \\
\hline \multicolumn{3}{|c|}{ Veterinary Access } \\
\hline Yes & 100 & 77 \\
\hline No & 30 & 23 \\
\hline \multicolumn{3}{|c|}{ Disease Prevention Practices } \\
\hline Vaccination & 16 & 12.3 \\
\hline Deworming & 7 & 5.4 \\
\hline Both deworming and vaccination & 56 & 43.1 \\
\hline None & 51 & 39.2 \\
\hline \multicolumn{3}{|c|}{ Cost of Treatments } \\
\hline Expensive & 35 & 27 \\
\hline Fair & 35 & 27 \\
\hline Cheep & 21 & 16 \\
\hline Not have treated & 39 & 30 \\
\hline
\end{tabular}

\section{Results of observational study}

Table 5: Work type, work time, load, floor structure of equine staled.

\begin{tabular}{|c|c|c|}
\hline Variable & Frequency (N) & Proportion (\%) \\
\hline \multicolumn{3}{|c|}{ Species of animal } \\
\hline Donkey & 55 & 46 \\
\hline Horse & 46 & 38.3 \\
\hline Mule & 19 & 15.3 \\
\hline \multicolumn{3}{|c|}{ Age of the animal in year } \\
\hline$<5$ & 10 & 8.33 \\
\hline 15-May & 90 & 75 \\
\hline$>15$ & 20 & 16.7 \\
\hline \multicolumn{3}{|l|}{ Sex } \\
\hline Male & 58 & 48.3 \\
\hline Female & 62 & 51.7 \\
\hline \multicolumn{3}{|c|}{ Work Type } \\
\hline Pack & 65 & 54.2 \\
\hline Draught & 30 & 25 \\
\hline Riding & 25 & 20.8 \\
\hline \multicolumn{3}{|c|}{ Body Condition of Equine } \\
\hline Poor & 41 & 34.2 \\
\hline Moderate & 48 & 40 \\
\hline Good & 31 & 25.8 \\
\hline \multicolumn{3}{|c|}{ Behaviour of Equine } \\
\hline
\end{tabular}




\section{International Journal of Environmental Sciences \& Natural Resources}

\begin{tabular}{|c|c|c|}
\hline Alert & 108 & 90 \\
\hline Depressed & 12 & 10 \\
\hline
\end{tabular}

Table 6: Proportion of work type between species $\mathrm{N}=120$.

\begin{tabular}{|c|c|c|c|c|}
\hline Work Type & Frequency/ N & Donkey & Horse & Mule \\
\hline Pack & 65 & $45(69 \%)$ & $17(26.3 \%)$ & $3(4.6 \%)$ \\
\hline Draught & 30 & $4(13.3 \%)$ & $26(86.7 \%)$ & - \\
\hline Riding & 25 & - & $7(28 \%)$ & $18(72 \%)$ \\
\hline
\end{tabular}

Table 7: Type and prevalence of lesions observed on the study animals $(\mathrm{N}=120)$.

\begin{tabular}{|c|c|c|}
\hline Type of lesion & Frequency (N) & Proportion (\%) \\
\hline \multicolumn{3}{|c|}{ Eye Abnormalities } \\
\hline Lacrimation & 24 & 20 \\
\hline Corneal opacity & 8 & 6.7 \\
\hline One eye blind & 9 & 7.5 \\
\hline \multicolumn{3}{|c|}{ Body Lesion and Abnormalities } \\
\hline Lip lesion & 18 & 15 \\
\hline Lameness & 15 & 12.5 \\
\hline Tail base lesion & 21 & 17.5 \\
\hline Back sore lesion & 14 & 11.7 \\
\hline Shoulder/chest lesion & 9 & 7.5 \\
\hline Ribs/flank lesion & 6 & 5 \\
\hline Limb lesion & 7 & 5.8 \\
\hline Scaly and thickened skin & 3 & 2.5 \\
\hline Belly lesion & 3 & 2.5 \\
\hline Head and neck region & 5 & 4.2 \\
\hline
\end{tabular}

A total of 120 Equidae were included in the observation study, of which $46 \%$ were donkeys, $38.4 \%$ horses, and $15.6 \%$ mules. Body condition assessment was done by looking the animal from both sides and the hind quarter without touching the animals and scored as "poor", "moderate" and "good". Accordingly, 34.2\%, $48 \%$ and $25.8 \%$ of the animals were in poor, moderate and good body condition status, respectively. Regarding the age of the animals, $8.3 \%, 75 \%$, and $16.7 \%$ were less than 5 years, $5-15$ years, and above 15 years, respectively. Sex wise $48.3 \%$ were males while $51.7 \%$ females. As to the work type $54.2 \%, 25 \%$ and $20.8 \%$ were used for pack, draught and riding purposes, respectively. Of the observed animals $90 \%$ were alert while $10 \%$ were depressed (Table 5). There was species difference in the type of work they used to do. The majority of (69\%) pack animals were donkeys while the predominant $(86.7 \%)$ draught animals were horses. Mules were the predominant animals used for riding $(72 \%)$ and small proportions (4.6\%) were used for pack purposes (Table 6). Assessment carried out at field level and market on the daytime. Body lesions were then recorded about

Table 8: proportion of lesion for different type of work in donkey, horse and mule.

\begin{tabular}{|c|c|c|c|c|}
\hline Type of Lesion & Frequency of Lesion & Pack & Draught & Riding \\
\hline Tail base & 21 & $14(66.7 \%)$ & $2(10 \%)$ & $5(23.8 \%)$ \\
\hline Lip and mouth & 18 & $2(11 \%)$ & $9(50 \%)$ & $7(38.9 \%)$ \\
\hline Lameness & 15 & $4(26.7 \%)$ & $11(73.3 \%)$ & - \\
\hline
\end{tabular}




\section{International Journal of Environmental Sciences \& Natural Resources}

\begin{tabular}{|c|c|c|c|c|}
\hline Back sore & 14 & $12(86 \%)$ & $1(7 \%)$ & $1(7 \%)$ \\
\hline Shoulder/ chest & 9 & $6(66.6 \%)$ & $3(22.2 \%)$ & $1(11 \%)$ \\
\hline Limb & 7 & $4(57 \%)$ & $2(28.6 \%)$ & $1(14 \%)$ \\
\hline Ribs /flank & 6 & $5(83 \%)$ & $1(16.7 \%)$ & - \\
\hline Head and neck region & 5 & $4(80 \%)$ & $1(20 \%)$ & - \\
\hline
\end{tabular}

\section{Discussion}

In this study, it was appreciated that the majority of respondents were male (83.8\%) and $74.7 \%$ of them were in between 15 and 45 age group. This finding agreed with previously done [20] with proportion of $73.3 \%$ in middle age group of (1845 years). Out of the total respondent (74.6\%) of equine owner, they provided to their equinea mixture of concentrate, cereal and straw/ hay. This finding was slightly higher than previously reported [21] with amount of $65 \%$ fed mixtures of concentrates and green grass but, as the study revealed that $35.4 \%$ of equine were affected by shortage of feed and about $23.1 \%$ owners of equine purchased feed from market to fulfill the feed requirement of their animals. The Concentrate feed was included bear residues and frushica, whereas the cereal feed included barely and bean. The study was categorized equine based on the types of work, such as draught, pack and ridden. "Draught" animals were those used for transport of goods and people by carts. "Pack" animals are those used for transport of goods by pack. "Ridden" animals are those used by owners this finding similar with Pritchard et al. (2005). According to result in Table 5: $54.3 \%$ of equine were used to pack purpose, $33.8 \%$ were for draught purpose and $16.9 \%$ were used to riding purpose. This finding was agreed with [13] which reported 50.91\%, 37.42\% and $5.23 \%$ were used for pack, draught, and ridding respectively. Most of the animals (65.4\%) used to work for 6-10 hours per day while few (34.6\%) work for 1-5 hrs. Regarding the working days per week a higher proportion $43.8 \%$ of equine work for 3-4 days, while $35.4 \%$ and $20.8 \%$ work for $5-7$ and $1-2$ days respectively this finding is in agree with [22].

Owners were didn't gave attention to their equine, in this case they were suffered from sun, rain or biting insects at markets or working sites. These have a potential to negatively affect their welfare and quality of life. The present study indicated that $55.4 \%$ of the respondents keep their animals outdoor in a fenced area without roof while $44.6 \%$ keep their animals indoor at night this finding consistent with [23] were found $42.0 \%$ and $31.4 \%$ owners used an open barn with fenced and closed shelter, respectively. However, this finding had lower respondent than reported [8] whose respondent (76.6\%) were provide shelter at home. Disease prevention practices by the equine owners included vaccination, deworming and both vaccination and deworming. However, $39.2 \%$ of the owners did not provide any prevention of diseases to their donkeys or horses, and $30 \%$ of respondent did not provide any treatment regardless of the presence and severity of diseases. This finding was highly lower than reported [6] with his finding $79.4 \%$ of the owners did not provide any treatment to their animals.
This study has revealed wound/ lesion as the most prevalent health problem of equines in and around Debre Birhan town, North Shoa which was observed in $84.2 \%$ equine studied. This finding is higher than the $72.15 \%$ prevalence reported in Hawassa, Southern Ethiopia [23]. This might be due to variation in management, geographical location and health care given to equines among these sites. In fact, majority of the poor people who obtain their income by providing transport service with the help of equines did not give attention for management, health care and welfare of their animals in the study area. Further analysis indicated that the frequency of occurrence of lesions of tail base, ribs/flank, chest/shoulder, and back sore, was relatively higher in pack type of work; whereas lip and mouth lesion, and lameness were seen more frequently in draught type of work. Similar finding were reported [1] where pack donkeys had a significantly higher proportion of tail/tail base lesions than draught animals. The causes for the development of these lesions are complex and multi factorial. Environmental factors, the type of harness material used (natural or synthetic), the fit of the harness, the behavior of the owner, the frequency of work and the load all contribute to the onset of health problems. The present finding is also in agreement with the observation. The current study revealed that draught type of work was likely to induce lip and mouth lesion (50\%) and lameness (73.3\%). These findings are consistent with other studies in Ethiopia and abroad $[3,18,19]$. These authors reported that lip lesions predominantly occur in horses and in draught type of work and less frequently develop in pack animals and lameness was more frequently occurred in animals with draught type of work due to continuous movement in various landscapes and on bumpy roads.

The present observation study has shown that $34.2 \%, 48 \%$ and $25.8 \%$ of the animals were in poor, moderate and good body condition score status, respectively. This finding is comparable to what has been reported [8] in which $31.6 \%, 47.3 \%$ and $20.3 \%$ of the study animals were in poor, moderate and good body condition, respectively. Poor body condition could be due to factors like poor management, shortage of nutrients because of scarcity of feed and less supplementary diets with heavy workload. It may be also be due to the equine spent a lot of time carrying the load on their back until it is sold; there was also overworking and over loading at market in this study area. There was species difference in the type of work done by the animals. It was observed that donkeys were most commonly used for pack type of work. Horses were the predominant equine for draught type of work while and mules were the most frequently used animal for riding. These results agree with a previous study [14]. 


\section{Conclusion and Recommendations}

The results of this study indicated that many of the equines working in the area were experiencing multiple welfare problems. Over loading with improper harnessing material, long time working without enough rest and enough rest, equine were carrying load until selling at market, shortage of feed, were welfare problem in this study area. Lesion such as lip, tail base, eye lacrimation and lameness were major problem in this study area. Recommendation should comprehensive awareness creation on equine welfare issues should be promoted through short training, extension service by the government and different NGOs such as donkey sanctuary, SPANA and Brook hospital. Policies and legal frameworks that used to support animal welfare issues and inspect animal facilities should be promoted in order to ensure animal welfare issues. Further investigation into the risk factors associated with each welfare issue is required before an intervention is made to improve the welfare problems of these working animals [24,25].

\section{References}

1. FAO (2003) FAO Statistical Database Website. Food and Agriculture Organization, Rome, Italy.

2. Dennison T, Khan G, Khan A, Pritchard J, Whay HA (2007) Comparative study of the welfare of equines working in the brick kilns of Multan and Peshawar, Pakistan.

3. Swann WJ (2006) Improving the welfare of working equine animals in developing countries. Applied animal Behavioral Science 100(1-2): 148-151.

4. Elina W (2010) Impact of veterinary assistance on the health of working horses. Nicaragua: Swedish University of Agricultural Science, Department of Animal Nutrition and Management, pp. 3-4.

5. Demelash B, Moges W (2006) Causes and factors Associated with Occurrence of External Injuries in working Equines in Ethiopia. International Journal of Applied Research in Veterinary Medicine, pp. 4: 1-7.

6. Fikru A, Tadese A, Gebreegziabher Z (2015) Prevalence of Equine Wound and Associated Risk Factors in and around Kombolcha Town, North Ethiopia, pp. 21-29.

7. Salim U, Haimanot D, Tadele K, Tilahun Z, Girma K (2015) Health and Welfare Related Assessment of Working Equine in and Around Batu Town, East Shoa, Central Ethiopia. Wollega University, School of Veterinary Medicine: Nature and Science 13: 5-6.

8. Amante M, Adisalem H, Bojia E, Eyob H, Bedasso M (2014) Health and Welfare Assessment of Working Equine, Nekemte, Ethiopia. American-Eurasian Journal of Scientific Research 9: 163-174.

9. Faith A, Burden N, Mariano H, Omar P, Andrew F (2009) Selected health and management issues facing working donkeys presented for veterinary treatment in rural Mexico. Some possible risk factors and potential intervention strategies 42(4): 597-605.

10. Smith D (2004) Final technical report R7350: Use and management of donkey by poor society's peri-urbanareas of Ethiopia. Center for Tropical Veterinary Medicine 2: 13-15.
11. Yilma J, Feseha G, Svendsen E, Mohammed A (1991) Health problems of working donkeys in Debrezeit and Menagesha Regions of Ethiopia. In: Fielding D, Pearson RA (Eds.), Donkeys, Mules and Horses in Tropical Agricultural Development. Edinburgh, pp. 151-155.

12. Sisay W (2013) Causes and Factors Associated with the Episode of External Injuries in Cart-Horses of Mekelle Town, Tigray North Ethiopia. Department of Veterinary Microbiology and Public health J Vet Adv 3: 4-7.

13. Solomon M, Rahmeto A (2010): Observation on major welfare problems of equine in Meskan district, Southern Ethiopia. Hawassa University, Faculty of Veterinary Medicine. Livestock Research for Rural Development 22(3): 13-17.

14. Fred O, Pascal K (2006) Extension Approaches to improving the welfare of working equines. Kenya Network for Dissemination of Agricultural Technologies (KENDAT), pp. 1-28.

15. Wilson RT (2002) Specific welfare problems associated with working horses. In: Waran N (Ed.), The welfare of horses. Dordrecht: Kluwer Academic Publishers, pp. 203-218.

16. Thrusfield M (2005) Veterinary epidemiology. ( $\left.2^{\text {nd }} e d n\right)$, Black well science, UK, pp. 182-189.

17. Getachew T (2014) Health constraints of Cart Horses in the Dry warm, Sub-moist tepid a Moist cool Climatic Zones of Central Ethiopia, Department of biomedical sciences, College of Veterinary Medicine and Agriculture, Addis Ababa University Ethiop Vet J 18(2): 99-107.

18. Main DCJ, Kent JP, Wemelsfelder F, OfnerE, Tuyttens FAM (2003) Application for methods of on farm welfare assessment. In: Proceedings of the Second International Workshop on the Assessment of Animal Welfare at Farm and Group Anim Welfare 12(4): 523-528.

19. Pritchardc JC, Lindberg AC, Main DCJ, Whay HR (2005) Assessment of the welfare of working horses, mules and donkeys, using health and behaviour parameters. Preventive Veterinary Medicine 69(3-4): 265283.

20. Biswas P, Dutt T, Patel M, Kamal R, Bharti PK, Sahu S (2013) Assessment of pack animal welfare in and around Bareilly city of India. Vet World 6(6): 332-336.

21. Mekuria S, Mulachew M, Abebe R (2013) Management practices and welfare problems encountered on working equids in Hawassa town, Southern Ethiopia. Journal of Veterinary Medicine and Animal Health 5: 243-250.

22. Dinka HB, Shelima A, Abalti T, Geleta T (2007) Socio-economic importance and management of carthorses in the mid rift valley of Ethiopia. Proceeding of an International Colloquium held at the Addis Ababa, pp. 181-188.

23. Biffa D, Woldemeskel M (2006) Causes and factors associated with occurrence of external injuries in working equines in Ethiopia. Intern J Appl Res Vet Med 4: 1-4.

24. Central Statistics Authority (2014) Livestock and Livestock Characteristics in Ethiopia Central Statistics.

25. Mohammed A (1991) Management and breeding aspects of donkeys around Awassa Ethiopia. Donkeys, Mules and Horses in Tropical Agricultural Development 185-188. 
(C) This work is licensed under Creative BY Commons Attribution 4.0 License

DOI: 10.19080/IJESNR.2019.21.556091
Your next submission with Juniper Publishers will reach you the below assets

- Quality Editorial service

- Swift Peer Review

- Reprints availability

- E-prints Service

- Manuscript Podcast for convenient understanding

- Global attainment for your research

- Manuscript accessibility in different formats ( Pdf, E-pub, Full Text, Audio)

- Unceasing customer service

Track the below URL for one-step submission https://juniperpublishers.com/online-submission.php 